\title{
Social Media and Decision-Making Process among Tourist: A Systematic Review
}

\author{
NOOR ALYANI NOR AZAZI \\ MASLINA MOHAMMED SHAED \\ Universiti Sains Malaysia
}

\begin{abstract}
Social media nowadays have a huge influence on the tourism sector. With the advancement of search engines, tourists can search for any information they need on their tourism preferences. Today, there are tons of social media websites (such as TripAdvisor, Trivago, Booking.com, Agoda.com) that can help the tourist to find and decide the best tourism places and activities around the world. Studies have shown that social media is one of the best tools that are used by a tourist in the decision-making process. This paper is written to have a better understanding and to find a gap in the studies related to this topic. Hence, this paper focuses on conceptual review using a systematic review based on 24 published journals and theses from 2015 to 2019 on the influence of social media and its impact on the decision-making process for the tourist. Based on the findings, the majority of the scholars supported that social media have a big impact on how people make the decision for their tourism destination. The gaps that derived from this review have proven that only limited studies have been conducted in Malaysia; most of the research used a quantitative approach; only a few studies have included the theory related to this issue, and the targeted respondents were mostly among young travellers. Therefore, further studies on the role of social media in the decision-making process can be done by focusing on these gaps, especially in the Malaysian context.
\end{abstract}

Keywords: Decision-making, influence, social media, tourism, tourist.

\section{INTRODUCTION}

Tourism is a social, cultural and economic phenomenon that entails the movement of people to countries or places outside their usual environment for personal or business/professional purposes. These people are called visitors (which may be either tourists or excursionists; residents or non-residents) and tourism has to do with their activities, some of which involve tourism expenditure (UNWTO, 2020). Tourism can also create memorable experiences for the tourists and some of the main purposes of travelling would be for leisure, exploration, relaxation, visitation and also religious purposes (Dusíková, 2018). Nowadays, tourism is mostly connected with the internet where tourists can always search for any information needed on the web and most of the platforms used by the tourist would be social media.

Social media is commonly known as a platform in a form of electronic communication that enables users to create, share or even exchange information, ideas, experience, images and videos (Ackland \& Kyosuke, 2015; Benea, 2014). It is also known as a tool for users to rely on for deciding on anything, make it in the retailing, health, education and even tourism industry. This happens because social media plays a major role in influencing the decision making for the users since a lot of information as well as experiences are shared virtually on the web nowadays (Benea, 2014, Veríssimo \& Menezes, 2016). In the tourism context, social media prepare platforms for tourists to find 
information and also share their knowledge and experience with other tourists. Reviews that are prepared by the tourists can be used as a tool or mechanism in helping other tourists decide on certain destinations or activities (Dusíková, 2018). Most of the tools of social media that are used by tourists are Facebook, Instagram, Twitter, TripAdvisor, Trivago, Booking.com and a lot more. These tools can influence the tourist decision making on their tourism preference and activities and this will be discussed below.

\section{LITERATURE REVIEW}

\section{Social media as a tool in tourism marketing}

Social media is known as a computer-based technology or also known as an internet-based application and mobile technologies that emerged from the technological foundation of Web 2.0 (Kaplan \& Haenlein, 2010; Benea, 2014) which is a business revolution in the computer industry with using the internet as a platform (O'Reilly, 2005). Social media turns communication into an interactive type of dialogue that allows the sharing of ideas and information through the virtual networks and it can be in a variety of forms like internet forums, blogs, podcasts, photographs and videos (Benea, 2014). From a marketer point of view, social media is a platform that allows marketers and the online communities to create meaningful conversations and content and it is free (Levinson \& Gibson, 2010; Benea, 2014). With the social media revolution, it is obvious that social media are used as a communication tool that allows anybody to communicate with everybody (Sterne, 2010; Baruah, 2012; Benea, 2014).

Social media is widely used for marketing in various sectors namely tourism, hotelier, business and retailing. Some of the examples of the social media that these businesses use other than their websites were Facebook, Twitter, Instagram, Pinterest, Flickr, YouTube and TripAdvisor (Sterne, 2010; Benea, 2014). Due to the increasing popularity of social media, many tourism providers such as hotels, travel agencies, and airline companies have been using this platform as one of their crucial marketing and communication tools (Sahin \& Sengün, 2015). According to Benea (2014) studies, all hotels in her studies have their own website and also multiple websites for their property including a Facebook page as the brand embraces a sub-brand were famous in Vienna. Benea (2014) studies also shows that most of the hotels in Viennese use social media to measure engagement levels of followers, rating, and reviews from customers and not measuring revenues and costs of the business. What the hoteliers want from the social media platform was to create awareness to the customers of their brand and product and also identify the customers' wants and needs. It is important to have an online presence not just to reach the customers but also to get to know the customers and personalize the provided service.

Nor'izah et al. (2018) also admit that social media play an important role in shaping the reputation and organization's image where all the information on the organizations shared and how they share it can influence the public perception on the organization. This was shown in their studies on the management of the airline companies in Malaysia. It is concluded that the airline companies in Malaysia need to manage their social media properly in answering the queries and comments from customer to avoid the unwanted crisis. Social media also have a significant influence on developing brand image where the social media word-of-mouth was found to be crucial in enhancing a company brand image. Other than that, the contents and reviews in the company's social media platform seem to give a huge impact on the consumer's perception of the brand image. Companies should know that social media advertising and promotions using social media platforms like 
Facebook and YouTube are one of the most important marketing efforts that can enhance the brand image. Consumers positive feedbacks through their reviews and comments can also help in enhancing the organization's brand image. (Raji et al., 2018).

In the tourism context, social media is also used as a tool that can strengthen the relationship with the tourists where tourism provider use this platform to create a bond of trust with the tourists and understating the impacts of the tourist services intangibility (Gentile et al., 2007; Veríssimo \& Menezes, 2016). Social media also helps to promote marketing experience where the tourism provider can establish emotional links between the brand or service with the tourists. This can also build a destination over people where the attributes of the destination get quality, competitive edge, innovation, cooperation and collaboration (Gretzel et al., 2000; Veríssimo \& Menezes, 2016). According to Veríssimo and Menezes (2016), social media plays a vital role in creating a good environment to enhance tourists' experience in hotel services and social media are also important for hotels' marketing managers in helping them to increase the quality of the services. In this context, there were two components of customer experience that were pointed out by social media which were lifestyle and relational. These two components include how social media plays an important role in consolidating the hotels' brand image by providing services to align with the customer's lifestyle together with their values and beliefs and also how the hotels connect with the customers through their services. There are four aspects that social media can help in enhancing the tourist's experience which is helping in marketing research, associating the brand image of the hotel, connection with the tourists and also creating a community of Fans to the hotels. (Gentile et al., 2007; Veríssimo \& Menezes, 2016). Social media also plays a significant role in medical tourism where trust is a crucial feature when it comes to the quality of the information. In the medical tourism context, the quality and information evaluation provided in the websites of the medical institutions are vital in persuading and influencing the tourist patient's decision-making process (Mohammad Ali et al., 2016).

Some tourism provider like the Tourism Australia encouraged the tourism industry in the region to embrace social media to promote their business and this tourism provider also offers their help by offering operators access to their global network Facebook fans and using this platform automatically gives all the tourism provider incredible free marketing (Tourism Australia, 2012; Zeng, 2013). If a tourism destination cannot connect with the virtual communities through social media, it can lose connection with millions of people who are connected with the virtual world. Around the world, millions of potential tourists are making researches for their potential tourism destination through the internet and social media by comparing the websites of other destinations based on the service and product experience provided by the destinations. Tourism provider invests a lot on their websites to increase their opportunities to attract tourists (Park \& Gretzel, 2007; Sahin \& Sengün, 2015). That just shows how crucial social media are in promoting and enhancing the tourism industry. It has been proven that social media is a vital tool for tourism marketing and social media also plays a huge influence on tourist decision making. This will be discussed more in the next section. 


\section{Social Media Influence on Tourist Decision Making}

Social media plays a major role in tourism decision making and these have been proven by numerous studies. Tourists nowadays search for every information on tourism destinations or activities like information, explanation, reviews, ratings, images and so on. This process is called as the information-collecting stage that usually takes place before any decision has been made by the tourists (Loncaric, 2013; Hamid et al., 2016).

Other than information and reviews, communications between the tourism provider with the potential tourist are also crucial where good quality communication through the tourism website will give an influence on the tourist decision making (Litvin et al., 2008; Abd Hamid et al., 2016). Communications in social media are also vital to determine tourist feedback, giving them clear information to make them understand the services given and also providing a knowledge satisfaction to the tourist (O'Connor, 2001; Hamid et al., 2016).

The social media platforms consist of travel-specific online communities, travel blogs, social networking sites which allows the tourist to communicate with other tourists, sharing their experience, comments, and opinions. Social media are considered as reliable and trustworthy as they can help the tourist to avoid uncertainty and increase their expectation on tourism destinations or activities (Xiang \& Gretzel, 2010; Dusíková, 2018).

Kaplan and Haenlein (2010) have classified social media into six types according to their level of social presence and self-disclosure and representation. These six classifications are social networking websites like Facebook, Linkedln; blogs, content communities like YouTube, Flickr; collaborative projects like Wikipedia, Wikitravel; virtual social worlds like Second Life; and virtual game worlds like World of Warcraft (Dusíková, 2018).

Social media is a very vital tool in the tourist decision making because tourist that use social media as their preference gets to know about the tourism destination and explore it through virtual spaces, gets to evaluate and narrow their selection of choices, avoid activities and destinations that are not recommended by other tourists, create images of the destinations, gives ideas and provide experience to others, reduce uncertainty and risk, helping in assisting tourism planning and also increase the confidence levels in tourists (di Pietro et al., 2012; Dusíková, 2018).

According to Sahin \& Sengün (2015), the young generations are mostly affected by reviews and comments in social media and most of them also contribute to sharing their tourism experience with media tools like photos and videos. Social media has a positive and also negative effect on the tourism industry and this is because the comments and reviews in social media can largely influence the tourist decision making towards their tourism preferences (Buhalis \& Rossides, 2012; Sahin \& Sengün, 2015; Dusíková, 2018). Through Sahin \& Sengün (2015) studies on the impact of social media, all the positive and negative reviews found in social media can play a huge influence on the tourist's decision. $41.1 \%$ of all respondents agreed that they have been influenced by positive comments on social media about holiday destinations and $47.8 \%$ of all respondents agreed that they have been influenced by negative comments on social media about holiday destinations (Sahin \& Sengün, 2015).

A post on social media can become a poll, collating tips and opinions. Together with Sahin and Sengün (2015), according to a survey done by Expedia (2020), Gen Z and millennials are mostly affected by the input on social media where a national study shows that $27 \%$ of Millennials have posted a potential tourism destination on social media to get opinions and comments before they start booking. Other than that, the same study also 
shows that $36 \%$ of gen $Z$ have decided on a tourism destination based on a social media posting they saw on the specific destination.

From the studies that have been conducted on the influence of social media, we can see that social media does play a big role and influence on tourist decision making. A lot of studies have been conducted in numerous countries but how about Malaysia? What are tools used to conduct a study on social media impact especially in the tourism context? Most importantly, what is the significance of these studies? Therefore, this review is very important to have a better understanding and to find a gap in the studies related to this topic.

\section{METHODOLOGY}

This is a conceptual paper using a systematic review. According to Gabrielsson (2017), there are four main steps in the systematic review process which are: 1) planning the review objective, 2) search through electronic, 3) analysis and review the coding and 4) reporting the findings. Therefore, this systematic review was based on 24 full-length open access journal articles and open access theses and dissertations from the website (working paper, BlogSpot, report, book chapters, conference proceedings, etc. excluded from this review). The researcher reviewed the literature from the period 2015 -2019. The findings from this paper are based on secondary sources of data. To identify relevant studies, the database searches using the keywords: "social media and tourism decision", "social media and travel decision making", "social media and destination decision making", "social media and trip decision making", "social media and holiday decision making", and "social media and decision making for a trip" using the Google scholar, Emerald full text, and Science Direct and Web of Science databases. Furthermore, this paper limits the search of the journal that contained "decision making" or "decision" or "destination choice" in tourism and "social media or social networking" from their titles and keywords. Other journal articles were excluded from this review.

\section{RESULT AND DISCUSSION}

This section outlines the review of the study related to the role of social media in tourism decision making. A summary of the reviews of 24 published articles from 2015 to 2019 is given in Table 1.

Based on the internet search, there was about 24 open access published journal and theses were found. In detail, 4 journals from 2015, 2 journals from 2016, 7 journals from 2017, 5 journals from 2018, and 6 journals from 2019. These studies have been done in several countries such as the United Kingdom, Finland, Austria, Australia, Sri Lanka, Russia, Turkey, Indonesia, India, Malaysia, and Albanian. As mentioned before, only a few studies have been conducted in Malaysia (Hua, Ramayah, Ping \& un-Hwa, 2017; Kamarul \& Nawar, 2017; Hamid et al., 2016; Bay, 2018). This is questionable because Malaysia is known for the tourism industry and Kuala Lumpur is ranked in the top ten of the most visited cities in the world (Traveller, 2018; CNNtravel, 2018 \& Cntraveler, 2019). Other than that, Malaysia was also ranked as one of the top five globally and highest in Southeast Asia for mobile social media penetration (NST, 2018).

In terms of research methodology, the majority of the study used a quantitative approach, followed by a qualitative approach, review paper, and mixed approach (quantitative and qualitative). Furthermore, most of the researchers have done data 
collection through an online survey. This method was significantly relevant since the targeted respondents are the people who use the Internet and social media. Meanwhile, the qualitative approach was done through interviews and focus group discussions.

One of the most important findings related to the review is the targeted respondents of the research. Several scholars from this review (e.g. Sugala \& Rizwan, 2019; Marcello, Maria, \& Julian, 2019; Angelika, 2015; Parsons, 2017; Ana \& Istudor, 2019; Daisy, 2017; Terttunen, 2017) have focused on young travellers or Millennials Generation (known as Generation Y); those individuals between the ages of 18 and 35 years. This cohort is the largest generation of Internet and social media users. Therefore, their impact and influence on social media in tourism sectors were huge and significant. Moreover, the most common and popular social media sites used for tourism sectors which been highlighted in many journals are Facebook, Instagram, Trip Advisor, Booking.com, YouTube, Twitter, Pinterest, Snapchat, Word Press, Four Square, LinkedIn, and Virtualtourist.com.

Briefly, based on 24 journals, there are few studies have applied some theory and model in their research. For instance, a study conducted by Parsons (2017) has discussed the theory of tourist decision-making behaviour by Engle, Blackwell and Miniard (1990). This theory is one of the popular theories and widely used on social media influence on travel decision-making which focuses on three phases decision-making namely pre-trip, during-trip and post-trip. While Min-En Aaron (2016) explained on Tourists' Cognitive Decision Making (TCDM) Model proposed by Chen (1998). This theory aimed at understanding the role of agents of influence towards choice outcomes which focus on some key elements such as travel intention, problem formulation, information search, latent influence from mediating variables, evaluation and implementation (Chen, 1998). Even though this model has been tested in various contexts, however, there are certain limitations of this model such as may not apply to all types of destination decisions (Min-En Aaron, 2016). Furthermore, a study by Dwityas and Briandana (2017) adapted a Travel Decision Making Model (Mathieson \& Wall, 1982) and Activities of Information Use in Social Media (McCann, 2008) in their study. This model interprets the use of social media in the decision making of tourism based on three phases: before, when and after the travel.

In short, another main finding of this study is related to the role of social media in the decision-making process in tourism. It is shown that the majority of scholars agreed that social media is a powerful tool that significantly has a positive impact on the decisionmaking process in tourism. Based on the review, it can be concluded that social media sites play a vital role in helping tourists to make the decision. Valuable information found in social media such as images, videos, reviews, feedback, rating, promotion, and popularity is very helpful in assisting tourist to make the decision before they travel. In fact, some tourists argued that all this information is more relevant than information provided by tourism websites and tourism providers. The photos were taken and shared by real travellers also very useful and important to increase the desire to travel than photos uploaded by service providers. Besides, it is unsurprising to find that a piece of combination information from social media and travel experiences shared by family members and friends have inspired others to make travel choices. Social media has brought an evolution impact in the tourism sector. 
Jurnal Komunikasi:

Malaysian Journal of Communication Jilid 36(4) 2020: 395-409

\begin{tabular}{|c|c|c|c|c|c|c|c|c|}
\hline No. & Author & Year & $\begin{array}{c}\text { Source of } \\
\text { Journal }\end{array}$ & Title of Journal & $\begin{array}{c}\text { Study } \\
\text { location }\end{array}$ & $\begin{array}{l}\text { Research } \\
\text { Method }\end{array}$ & IV & DV \\
\hline 1. & Angelika Beham & 2015 & $\begin{array}{c}\text { Thesis (Vienna } \\
\text { University) }\end{array}$ & $\begin{array}{c}\text { Role of Social Media in Generation Y } \\
\text { travellers' travel decision making } \\
\text { process }\end{array}$ & Austria & Qualitative & social media & $\begin{array}{l}\text { travel decision } \\
\text { making process }\end{array}$ \\
\hline 2. & Anna Terttunen & 2017 & $\begin{array}{l}\text { Thesis } \\
\text { (University of } \\
\text { Applied } \\
\text { Sciences, Haa- } \\
\text { ga Helia) }\end{array}$ & $\begin{array}{c}\text { The influence of Instagram on } \\
\text { consumers' travel planning and } \\
\text { destination choice }\end{array}$ & Finland & Quantitative & $\begin{array}{l}\text { social media } \\
\text { (specifically } \\
\text { Instagram) }\end{array}$ & $\begin{array}{l}\text { travel planning and } \\
\text { destination choice }\end{array}$ \\
\hline 3. & Bay Sheue Wen & 2018 & $\begin{array}{l}\text { Thesis } \\
\text { (Universiti } \\
\text { Tunku Abdul } \\
\text { Rahman) }\end{array}$ & $\begin{array}{l}\text { The Effects of Social Media on } \\
\text { Consumer Behaviour in Tourism: A } \\
\text { Study Among University Students. }\end{array}$ & Malaysia & Quantitative & social media & $\begin{array}{l}\text { consumer } \\
\text { behaviour in } \\
\text { tourism }\end{array}$ \\
\hline 4. & Daisy Magill & 2017 & $\begin{array}{l}\text { Thesis } \\
\text { (Cardiff } \\
\text { Metropolitan } \\
\text { University) }\end{array}$ & $\begin{array}{l}\text { The influence of social media on the } \\
\text { overseas travel choices of Generation } \\
\text { Y. }\end{array}$ & UK & $\begin{array}{l}\text { Quantitative } \\
\text { and } \\
\text { Qualitative }\end{array}$ & social media & $\begin{array}{c}\text { holiday decision } \\
\text { process }\end{array}$ \\
\hline 5. & $\begin{array}{l}\text { Dean Creevey, Etain } \\
\text { Kidney and Glenn } \\
\text { Mehta }\end{array}$ & 2019 & $\begin{array}{l}\text { Journal of } \\
\text { Travel \& } \\
\text { Tourism } \\
\text { Marketing }\end{array}$ & $\begin{array}{l}\text { From dreaming to believing: a review } \\
\text { of consumer engagement behaviours } \\
\text { with brands' social media content } \\
\text { across the holiday travel process }\end{array}$ & - & Review & $\begin{array}{l}\text { social media } \\
\text { user } \\
\text { engagement } \\
\text { behaviors }\end{array}$ & travel process \\
\hline 6. & $\begin{array}{l}\text { Hannah Louise } \\
\text { Parsons }\end{array}$ & 2017 & $\begin{array}{l}\text { Thesis } \\
\text { (Cardiff } \\
\text { Metropolitan } \\
\text { University) }\end{array}$ & $\begin{array}{c}\text { Does Social Media Influence an } \\
\text { Individual's Decision to Visit Tourist } \\
\text { Destinations? Using A Case Study of } \\
\text { Instagram }\end{array}$ & UK & $\begin{array}{l}\text { Quantitative } \\
\text { and } \\
\text { Qualitative }\end{array}$ & social media & $\begin{array}{l}\text { individual's decision } \\
\text { to visit a tourist } \\
\text { destination }\end{array}$ \\
\hline 7. & $\begin{array}{l}\text { Hossein Nezakati, } \\
\text { Asra Amidi, Yusmadi } \\
\text { Yah Jusoh, Shayesteh } \\
\text { Moghadas, } \\
\text { Yuhanis Abdul Aziz, } \\
\text { Roghayeh } \\
\text { Sohrabinezhadtalemi }\end{array}$ & 2015 & $\begin{array}{l}\text { ScienceDirect } \\
\text { Procedia - Social } \\
\text { and Behavioral } \\
\text { Sciences }\end{array}$ & $\begin{array}{l}\text { Review of Social Media Potential on } \\
\text { Knowledge Sharing and } \\
\text { Collaboration in Tourism Industry }\end{array}$ & - & $\begin{array}{l}\text { Systematic } \\
\text { Review }\end{array}$ & - & $\begin{array}{l}\text { knowledge sharing } \\
\text { in social media in } \\
\text { tourism sector }\end{array}$ \\
\hline
\end{tabular}




\begin{tabular}{|c|c|c|c|c|c|c|c|c|}
\hline No. & Author & Year & $\begin{array}{c}\text { Source of } \\
\text { Journal }\end{array}$ & Title of Journal & $\begin{array}{c}\text { Study } \\
\text { location }\end{array}$ & $\begin{array}{l}\text { Research } \\
\text { Method }\end{array}$ & IV & DV \\
\hline 8. & $\begin{array}{l}\text { Irma Shyl, } \\
\text { Vjollca Hysi (Panajoti) }\end{array}$ & 2015 & $\begin{array}{c}\text { European } \\
\text { Journal of } \\
\text { Interdisciplinary } \\
\text { Studies }\end{array}$ & $\begin{array}{l}\text { Social Media and its Impact on } \\
\text { Decision Making for Trip }\end{array}$ & Albanian & Quantitative & Social Media & $\begin{array}{l}\text { decision making for } \\
\text { trip }\end{array}$ \\
\hline 9. & $\begin{array}{l}\text { Juho Pesonena Katja } \\
\text { Pasanen }\end{array}$ & 2017 & $\begin{array}{l}\text { Information and } \\
\text { Communication } \\
\text { Technologies in } \\
\text { Tourism }\end{array}$ & $\begin{array}{l}\text { A closer look at tourist information } \\
\text { search behavior when travelling } \\
\text { abroad: what is the role of online } \\
\text { marketing in choice of destination? }\end{array}$ & Finland & Qualitative & $\begin{array}{l}\text { role of online } \\
\text { marketing }\end{array}$ & destination choice \\
\hline 10. & $\begin{array}{l}\text { Kamarul Faizal } \\
\text { Hashima, Nawar } \\
\text { Abbood Fadhil }\end{array}$ & 2017 & $\begin{array}{l}\text { ScienceDirect } \\
\text { Procedia } \\
\text { Computer } \\
\text { Science }\end{array}$ & $\begin{array}{l}\text { Engaging with Customer Using Social } \\
\text { Media Platform: A Case } \\
\text { Study of Malaysia Hotels }\end{array}$ & Malaysia & Qualitative & $\begin{array}{c}\text { level of } \\
\text { engagement }\end{array}$ & $\begin{array}{l}\text { social media } \\
\text { platform }\end{array}$ \\
\hline 11. & $\begin{array}{l}\text { Lim Yan Hua, T. } \\
\text { Ramayah, Teoh Ai } \\
\text { Ping \& Cheah Jun- } \\
\text { Hwa (Jacky) }\end{array}$ & 2017 & $\begin{array}{l}\text { Business and } \\
\text { Economics } \\
\text { Journal }\end{array}$ & $\begin{array}{c}\text { Social Media as a Tool to Help Select } \\
\text { Tourism Destinations: The Case of } \\
\text { Malaysia }\end{array}$ & Malaysia & Quantitative & social media & $\begin{array}{l}\text { tourism } \\
\text { destinations }\end{array}$ \\
\hline 12. & $\begin{array}{l}\text { Marcello Mariani, } \\
\text { Maria Ek Styven, } \\
\text { Julian K. Ayeh }\end{array}$ & 2019 & $\begin{array}{l}\text { International } \\
\text { Journal of } \\
\text { Contemporary } \\
\text { Hospitality } \\
\text { Management }\end{array}$ & $\begin{array}{l}\text { Using Facebook for travel decision- } \\
\text { making: an international study of } \\
\text { antecedents }\end{array}$ & - & Quantitative & $\begin{array}{l}\text { social media } \\
\text { (specifically } \\
\text { Facebook) }\end{array}$ & $\begin{array}{l}\text { travel decision- } \\
\text { making }\end{array}$ \\
\hline 13. & $\begin{array}{l}\text { Maria-Irina Ana, } \\
\text { Laura-Gabriela } \\
\text { Istudor }\end{array}$ & 2019 & $\begin{array}{l}\text { Management } \\
\text { Dynamics in the } \\
\text { Knowledge } \\
\text { Economy }\end{array}$ & $\begin{array}{c}\text { The Role of Social Media and User- } \\
\text { Generated-Content in } \\
\text { Millennials' Travel Behavior }\end{array}$ & - & Quantitative & $\begin{array}{l}\text { Social Media } \\
\text { and User- } \\
\text { Generated } \\
\text { Content }\end{array}$ & $\begin{array}{l}\text { Millennial } \\
\text { consumers' travel } \\
\text { behavior }\end{array}$ \\
\hline 14. & Min-En Aaron Tham & 2016 & $\begin{array}{l}\text { Thesis (Monash } \\
\text { University) }\end{array}$ & $\begin{array}{c}\text { The Influence of Social Media in } \\
\text { Destination Choice }\end{array}$ & Melbourne & Qualitative & social media & destination choice \\
\hline 15. & $\begin{array}{l}\text { Nikita Singhal, Varsha } \\
\text { Khattri }\end{array}$ & 2018 & $\begin{array}{l}\text { International } \\
\text { Journal of } \\
\text { Management, IT } \\
\text { \& Engineering }\end{array}$ & $\begin{array}{c}\text { Impact of Social Media on Consumer } \\
\text { Attitude and Purchase Decision in } \\
\text { Travel } \\
\text { and Tourism Industry }\end{array}$ & India & Quantitative & social media & $\begin{array}{l}\text { - consumers } \\
\text { behavior } \\
\text { - purchase decision } \\
\text { in Indian travel and } \\
\text { tourism industry }\end{array}$ \\
\hline
\end{tabular}


Jurnal Komunikasi:

Malaysian Journal of Communication

Jilid 36(4) 2020: 395-409

\begin{tabular}{|c|c|c|c|c|c|c|c|c|}
\hline No. & Author & Year & $\begin{array}{c}\text { Source of } \\
\text { Journal }\end{array}$ & Title of Journal & $\begin{array}{c}\text { Study } \\
\text { location }\end{array}$ & $\begin{array}{l}\text { Research } \\
\text { Method }\end{array}$ & IV & DV \\
\hline 16. & $\begin{array}{l}\text { Nindyta Aisyah } \\
\text { Dwitya, Rizki } \\
\text { Briandana }\end{array}$ & 2017 & $\begin{array}{l}\text { International } \\
\text { Journal of } \\
\text { Humanities and } \\
\text { Social Science }\end{array}$ & $\begin{array}{c}\text { Social Media in Travel Decision Making } \\
\text { Process }\end{array}$ & Indonesia & Qualitative & social media & $\begin{array}{l}\text { travel decision- } \\
\text { making process }\end{array}$ \\
\hline 17. & $\begin{array}{l}\text { Orhan Icoz, Anıl } \\
\text { Kutuk, } \\
\text { Onur Icoz }\end{array}$ & 2018 & $\begin{array}{l}\text { Revista de } \\
\text { Turismo y } \\
\text { Patrimonio } \\
\text { Cultural }\end{array}$ & $\begin{array}{l}\text { Social media and consumer buying } \\
\text { decisions } \\
\text { in tourism: The case of Turkey }\end{array}$ & Turkey & Quantitative & social media & $\begin{array}{l}\text { consumer's } \\
\text { decision- } \\
\text { making } \\
\text { process in tourism }\end{array}$ \\
\hline 18. & $\begin{array}{l}\text { Ravindran, M. } \\
\text { Nagamalar, P. Uma } \\
\text { Rani }\end{array}$ & 2018 & $\begin{array}{l}\text { Eurasian Journal } \\
\text { of Analytical } \\
\text { Chemistry }\end{array}$ & $\begin{array}{l}\text { Social Media Sources (SMS) Influence } \\
\text { on Tourism Choice Decisions }\end{array}$ & $\begin{array}{l}\text { Madurai, } \\
\text { Tamilnadu }\end{array}$ & Quantitative & $\begin{array}{l}\text { social media } \\
\text { sources }\end{array}$ & $\begin{array}{l}\text { decisions of tourism } \\
\text { consumers }\end{array}$ \\
\hline 19. & $\begin{array}{l}\text { Rosemary Matikiti- } \\
\text { Manyevere, } \\
\text { Martinette Kruger }\end{array}$ & 2019 & $\begin{array}{l}\text { African Journal } \\
\text { of Hospitality, } \\
\text { Tourism and } \\
\text { Leisure }\end{array}$ & $\begin{array}{c}\text { The role of social media sites in trip } \\
\text { planning and } \\
\text { destination decision-making processes }\end{array}$ & - & Review & $\begin{array}{l}\text { social media } \\
\text { sites }\end{array}$ & trip decision making \\
\hline 20. & $\begin{array}{l}\text { Sergey P. Kazakov, } \\
\text { Marina D. } \\
\text { Predvoditeleva }\end{array}$ & 2015 & $\begin{array}{l}\text { Thesis (National } \\
\text { Research } \\
\text { University } \\
\text { Higher School of } \\
\text { Economics) }\end{array}$ & $\begin{array}{c}\text { How Travelers Use Online and Social } \\
\text { Media Channels to Make Hotel Choice } \\
\text { Decisions. } \\
\text { A Comparative Study of Russian } \\
\text { Federation and American Tourists' } \\
\text { Online Consumer Behavior }\end{array}$ & Russia & Quantitative & social media & $\begin{array}{l}\text { hotel choice } \\
\text { decisions }\end{array}$ \\
\hline 21. & Sneha Naidu & 2019 & $\begin{array}{l}\text { International } \\
\text { Journal of } \\
\text { Management, } \\
\text { Technology and } \\
\text { Engineering }\end{array}$ & $\begin{array}{l}\text { A Study on the Influence of Social } \\
\text { Media on Tourist Psychology }\end{array}$ & Bengaluru & Quantitative & social media & $\begin{array}{l}\text { psychology of } \\
\text { potential tourist's } \\
\text { decision to make } \\
\text { travel choices }\end{array}$ \\
\hline
\end{tabular}


Social Media and Decision-Making Process among Tourist: A Systematic Review

Noor Alyani Nor Azazi \& Maslina Mohammed Shaed

\begin{tabular}{|c|c|c|c|c|c|c|c|c|}
\hline No. & Author & Year & $\begin{array}{c}\text { Source of } \\
\text { Journal }\end{array}$ & Title of Journal & $\begin{array}{c}\text { Study } \\
\text { location }\end{array}$ & $\begin{array}{l}\text { Research } \\
\text { Method }\end{array}$ & IV & DV \\
\hline 22. & $\begin{array}{l}\text { Sugala Senanayake, } \\
\text { Rizwan Anise }\end{array}$ & 2019 & $\begin{array}{l}\text { Colombo } \\
\text { Journal of } \\
\text { Advanced } \\
\text { Research }\end{array}$ & $\begin{array}{c}\text { The Influence of Social Media on } \\
\text { Millennial's Travel Decision Making } \\
\text { Process }\end{array}$ & Sri Lanka & Quantitative & Social Media & $\begin{array}{l}\text { Travel Decision } \\
\text { making Process }\end{array}$ \\
\hline 23. & Tereza Dusíková & 2018 & $\begin{array}{l}\text { Thesis } \\
\text { (State } \\
\text { University of } \\
\text { New York) }\end{array}$ & $\begin{array}{c}\text { The Impact of Social Media on the } \\
\text { Decision-making Process in Travel } \\
\text { Planning }\end{array}$ & - & - & social media & travelers' decisions \\
\hline 24. & $\begin{array}{l}\text { Hamid, Wee, } \\
\text { Hanafiah \& Asri }\end{array}$ & 2016 & $\begin{array}{c}\text { Heritage, } \\
\text { Culture and } \\
\text { Society, In } \\
\text { Radzi et al. (Eds) } \\
2016 \text { Taylor \& } \\
\text { Francis Group, }\end{array}$ & $\begin{array}{l}\text { The effect of social media on tourists' } \\
\text { decision to travel to Islamic } \\
\text { destination: A case of Malaysia }\end{array}$ & Malaysia & Quantitative & $\begin{array}{l}\text { attributes of } \\
\text { social media }\end{array}$ & decision to travel \\
\hline
\end{tabular}




\section{CONCLUSION}

In conclusion, based on the articles reviewed from 2015 to 2019, it can be summarized that there are many studies that have examined the influence of social media on the decisionmaking process in tourism. Findings also have shown that social media is a crucial tool for tourist and tourism marketing. However, in the meantime, only limited studies have been focused on this topic in Malaysia. Therefore, there has been an increased recognition that more attention needs to be paid to this area. Several studies in tourism also suggested that there is a need to enhance the role of social media to boost the promotion of tourism sectors and to help the traveller to decide their holiday destination. The research gaps found in this paper also useful for future researchers to investigate and to conduct a better study. In addition, future studies may need to investigate the positive and negative impact of social media on tourist decision-making and make improvements on it and to make full use of this platform. It can be concluded that this paper is very crucial to provide a better understanding and to highlight the significant influence of social media on tourist decisionmaking. This review is hoped to be able to contribute to the body of knowledge and act as a guideline for future researchers in related fields.

\section{BIODATA}

Noor Alyani Binti Nor Azazi is a senior lecturer in the Development Planning and Management section in the School of Social Sciences, Universiti Sains Malaysia. Her research interests revolve around urban development, the influence of higher learning institution on urban development and experience economy. Email: nooralyani@usm.my

Maslina Binti Mohammed Shaed is a senior lecturer at the School of Social Sciences, Universiti Sains Malaysia. Her research interests mainly in the area of management, gender and development, human resource development, developmental science, and human science development. Email: maslina.shaed@usm.my 


\section{REFERENCES}

Ackland, R., \& Kyosuke, T. (2015). Development impact of social media (English) (World Development Report Background Papers). World Bank. Washington, DC: World Bank Group. Retrieved from http://documents.worldbank.org/ curated/en/3 73231467 9945830 78/Development-impact-of-social-media

Baruah, T. D. (2012). Effectiveness of social media as a tool of communication and its potential for technology enabled connections: A micro-level study. International Journal of Scientific and Research Publications, 2(5), 2250-3153.

Bay, S. W. (2018). The effects of social media on consumer behaviour in tourism: A study among university students (Doctoral dissertation, UTAR, Malaysia). Retrieved from http://eprints.utar.edu.my/2930/1/IA-2018-BSW-1400267.pdf

Benea, I. A. (2014). Influences of social media on the tourism and hospitality industry (Dissertation). $\quad$ Retrieved from https://www.modul.ac.at/uploads/files/Theses/Bachelor/BBA_thesis_BENEA_loana. pdf

Buhalis, D., \& Law, R. (2008). Progress in information technology and tourism management: 20 years on and 10 years after the Internet-The state of eTourism research. Tourism Management, 29(4), 609-623.

CNNtravel. (2018). Most visited: World's top cities for tourism. Retrieved from https://edition.cnn.com/travel/article/most-visited-cities-euromonitor2018/index.html

Cntraveler. (2019). The 10 most popular cities of 2019. Retrieved from https://www.cntraveler.com/galleries/2015-06-03/the-10-most-visited-cities-of2015-london-bangkok-new-york

Dean, C., Etain, K., \& Glenn, M. (2019). From dreaming to believing: A review of consumer engagement behaviours with brands' social media content across the holiday travel process. Journal of Travel \& Tourism Marketing, 36(6), 679-691. https://doi.org/10.1080/10548408.2019.1624242

di Pietro, L., Di Virgilio, F., \& Pantano, E. (2012). Social network for the choice of tourist destination: Attitude and behavioural intention. Journal of Hospitality and Tourism Technology, 3(1), 60-76.

Dusíková, T. (2018). The impact of social media on the decision-making process in travel planning (Dissertation, State University of New York Empire State College). Retrieved from https://elearning.unyp.cz/pluginfile.php/58141/mod_data/content/3522 /Dusikova_Tereza_512546_Bachelor\%20Thesis.pdf

Dwityas, N. A., \& Briandana, R. (2017). Social media in travel decision making process. International Journal of Humanities and Social Science, 7(7), 291-292.

Expedia. (2018). Generation on the move. 2018 Expedia and the center for generational kinetics. Retrieved from https://viewfinder.expedia.com/wpcontent/uploads/2018/01/Expedia-Generations-on-the-Move.pdf

Gabrielsson, J. (2017). Corporate governance and entrepreneurship: Current states and future directions. In, Handbook of research on corporate governance and entrepreneurship. Cheltenham, UK: Edward Elgar Publishing.

Gentile, C., Spiller, N., \& Noci, G. (2007). How to sustain the customer experience: An overview of experience components that co-create value with the customer. European Management Journal, 25(5), 395-410. 
Gretzel, U., Yuan, Y., \& Fesenhaier, D. (2000). Preparing for the new economadvertising strategies and change in destination marketing organization. Journal of Travel Research, 39, 149-156.

Hamid, Z. A., Wee, H., Hanafiah, M. H., \& Asri, N. A. A. (2016). The effect of social media on tourists' decision to travel to Islamic destination: A case of Malaysia. Heritage, Culture and Society. 3rd International Hospitality and Tourism Conference, IHTC 2016 and 2nd International Seminar on Tourism, ISOT 2016. CRC Press/Balkema, 2016.

Hua, L. Y., Ramayah, T., Ping, T. A., \& Jun-Hwa, C. (Jacky). (2017). Social media as a tool to help select tourism destinations: The case of Malaysia. Information Systems Management, 34(3), 265-279. https://doi.org/10.1080/10580530.2017.1330004

Icoz, O., Kutuk, A., \& Icoz, O. (2018). Social media and consumer buying decisions in tourism: The case of Turkey. Revista de Turismo y Patrimonio Cultural, 16(4), 1051-1066.

Kaplan, A. M., \& Haenlein, M. (2010). Users of the world, unite! The challenges and opportunities of social media. Business Horizons, 53(1), 59-68.

Levinson, J. C., \& Gibson, S. (2010). Guerrilla social media marketing: 100+ weapons to grow your online influence, attract customers, and drive profits. Irvine, California: Entrepreneur Press.

Litvin, S. W., Goldsmith, R. E., Pan, B. (2008). Electronic word-of-mouth in hospitality and tourism management. Tour Management, 29, 458-468.

Loncaric, L. B. (2013). Importance of DMO websites in tourist destination selection. Congress Proceedings Marketing in a Dynamic Environment - Academic and Practical Insights. Retrieved from https://bib.irb.hr/datoteka/666923.Loncaric_Basan_GligoraMarkovic.pdf

Magill, D. (2017). The influence of social media on the overseas travel choices of Generation $Y$ (Doctoral dissertation, Cardiff Metropolitan University).

Maria-Irina, A. N. A., \& Istudor, L. G. (2019). The role of social media and user-generatedcontent in millennials' travel behavior. Management Dynamics in the Knowledge Economy, 7(1), 87-104.

Mariani, M., Ek Styven, M., \& Ayeh, J. K. (2019). Using Facebook for travel decision-making: an international study of antecedents. International Journal of Contemporary Hospitality Management, 31(2), 1021-1044.

Matikiti-Manyevere, R., \& Kruger, M. (2019). The role of social media sites in trip planning and destination decision-making processes. African Journal of Hospitality, Tourism and Leisure, 8(5), 1-10.

McCarthy, L., Stock, D., \& Verma, R. (2010). How travelers use online and social media channels to make hotel-choice decisions. Cornell Hospitality Report, 10(18), 6-18.

Min-En, A. T. (2016). The influence of social media in destination choice (Doctoral dissertation, Cardiff Metropolitan University).

Mohammad Ali Moslehifar, Noor Aireen Ibrahim, \& Shanti C. Sandaran. (2016). Assessing the quality of trust features on website content of top hospitals for medical tourism consumers. Jurnal Komunikasi: Malaysian Journal of Communication, 32(1), 472-493.

Nezakati, H., Amidi, A., Jusoh, Y. Y., Moghadas, S., Aziz, Y. A., \& Sohrabinezhadtalemi, R. (2015). Review of social media potential on knowledge sharing and collaboration in tourism industry. Procedia-social and behavioral sciences, 172, 120-125. 
Nor'izah Ahmad, Sharmini Abdullah, \& Narimah Ismail. (2018). Company Facebook and crisis signal: The case of Malaysian Airline Companies. Jurnal Komunikasi: Malaysian Journal of Communication, 34(1), 270-283.

O'Connor, P., \& Frew, A. J. (2001). Expert perceptions on the future of hotel electronic distribution channels. https://doi.org/10.1177/0010880402433003

O'Reilly, T. (2005). What is web 2.0 design patterns and business models for the next generation of software. O'Reilly Net. Retrieved from http://www.oreillynet.com /pub/a/oreilly/tim/news/2005/09/30/what-is-web-20.html

Park, Y. A., \& Gretzel, U. (2007). Success factors for destination marketing web sites: A qualitative meta-analysis. Journal of Travel Research, 10(4), 46-63.

Parsons, H. (2017). Does social media influence an individual's decision to visit tourist destinations? Using a case study of Instagram (Doctoral dissertation, Cardiff Metropolitan University).

Pesonen, J., \& Pasanen, K. (2017). A closer look at tourist information search behaviour when travelling abroad: What is the role of online marketing in choice of destination?. In Neidhardt, J., \& Wörndl, W. (Eds.), Information and communication technologies in tourism (pp. 431-443). Switzerland: Springer.

Raji Ridwan Adetunji, Sabrina Mohd Rashid, \& Mohd Sobhi Ishak. (2018). Social media marketing communication and consumer-based brand equity: An account of automotive brands in Malaysia. Jurnal Komunikasi: Malaysian Journal of Communication, 34(1), 1-19.

Ravindran, D., Nagamalar, M., \& Rani, D. U. (2018). Social media sources (SMS) influence on tourism choice decisions. Eurasian Journal of Analytical Chemistry, 13(6b), 177-182.

Sahin, G. G., \& Sengün, G. (2015). The effects of social media on tourism marketing: A study among university students. Management and Administrative Sciences Review, 4(5), $772-786$.

Shyle, I., \& Hysi, V. (2015). Social media and its impact on decision making for trip. European Journal of Interdisciplinary Studies, 1(1), 8-15.

Singhal, N., \& Khattri, V. (2018). Impact of social media on consumer attitude and purchase decision in travel and tourism industry. International Journal of Management, IT and Engineering, 8(5), 151-162.

Sneha. N. (2019). A study on the influence of social media on tourist psychology. International Journal of Management, Technology and Engineering, 9(1), 537-545.

Sterne, J. (2010). Social media metrics: How to measure and optimize your marketing investment. Hoboken, N.J: John Wiley.

Sugala, S., \& Rizwan, A. (2019). The influence of social media on millennial's travel decision making process. Colombo Journal of Advanced Research, 1(1), 192-205.

Terttunen, A. (2017). The influence of Instagram on consumers' travel planning and destination choice (Dissertation). Retrieved from https://www.theseus.fi/ bitstream/handle/10024/129932/Terttunen_Anna.pdf?sequence $=1$

Tourism Australia. (2012). Tourism Australia urges industry to get social media ready. Retrieved from https://www.tourismcambodia.com/news/worldnews/ 5549/tourism-australia-urges-industry-to-get-social-media-ready.htm

Traveller. (2018). World's most popular cities for tourists 2018 named. Retrieved from https://www.traveller.com.au/worlds-most-popular-cities-for-tourists-2018-namedh164d2 
UNWTO. (2020). The world tourism organization. glossary of tourism terms. Retrieved from https://www.unwto.org/glossary-tourism-terms

Veríssimo, M., \& Menezes, N. (2016). Social media as a tool to enhance customer experience in hospitality industry. Revista Portuguesa de marketing, 34, 23-30.

Xiang, Z., \& Gretzel, U. (2010). Role of social media in online travel information search. Tourism Management, 31, 179-188.

Zeng, B. (2013). Social media in tourism. Journal of Tourism \& Hospitality, 2, 1-2. 